\title{
Uygulamalı Fotoğrafçılık Derslerinin Uzaktan Eğitim Yoluyla Yürütülmesine İlişkin Bir Değerlendirme
}

DOI: $10.26466 /$ opus. 903693

\author{
* \\ Erdi Okan Yilmaz* \\ * Öğr. Gör. Dr., Uşak Üniversitesi, Uzaktan Eğitim Uygulama ve Araştırma Merkezi, Uşak/Türkiye \\ E-Posta: erdi.yilmaz@usak.edu.tr \\ ORCID: $\underline{0000-0002-7423-725 X}$
}

\section{Öz}

COVID-19 pandemi sürecinde, kuramsal derslerle beraber birçok uygulamalı ders, uzaktan eğitim yoluyla verilmek durumunda kalınmıştır. Uygulamalı bir dersin uzaktan eğitim yoluyla verilmesine ilişskin alanyazın incelendiğinde, uygulamalı derslerin kuramsal ağırlıklı yürütülmesinden dolayı sıkıntılar yaşandığı ve öğrenci performansımı olumsuz yönde etkilediğine ilişkin araştırma sonuçlarına rastlanmaktadır. Bu araştırmanın amacı, iletişim fakültelerinde lisans düzeyinde örgün öğretimde uygulamalı olarak yürütülmekte olan fotoğrafçllı derslerinin, pandemi sürecinde uzaktan eğitim yoluyla yürütülmesine ilişkin öğrenci algılarının incelenerek değerlendirilmesidir. Araştırmada karma açıklayıcı desen kullanılmıştır. Fotoğrafçıllk dersi 14 hafta boyunca çevrimiçi olarak yürütülmüş, ardından araştırmacı tarafindan açık ve kapalı uçlu sorulardan oluşan 10 soruluk öğrenci algısı anketi ile görüşme formu geliştirilerek, 2020-2021 öğretim yılı güz dönemi bitiminde öğrencilere çevrimiçi olarak uygulanmıştır. Araştırmanın örneklemini, Uşak Üniversitesi İletişim Fakültesinde öğrenim gören 120 lisans öğrencisi oluşturmaktadır. Öğrencilerden elde edilen nicel ve nitel veriler analiz edilerek raporlanmıştır. Araştırma sonucunda, uygulamah olarak verilmekte olan fotoğrafçıllk derslerinin, uzaktan eğitim yoluyla verilmesinden öğrencilerin genel olarak memnuniyet duymadıkları, öğrenme performanslarının olumsuz etkilendiğini düşündükleri, derslerin kuramsal bölümlerinin verimli olduğunu düşünürlerken uygulamalı kısımlarının verimsiz olduğunu düşündükleri, çevrimiçi derslerde materyal kullanımın faydalı buldukları ve uygulamalı derslerin uzaktan eğitim yoluyla yürütülmesini istemedikleri sonuçlarına ulaşılmıştır. Bu araştırmanın sonunda uygulamalı fotoğrafç̧lık derslerinin kuramsal kısımlarının uzaktan eğitim yoluyla verilebileceği, uygulamalı kısımlarm ise yüz yüze yapılmasının tercih edilmesi önerilmektedir.

Anahtar Kelimeler: Fotoğrafçılık Dersi, Uzaktan Ĕ̆itim, Uygulamalı Fotoğrafçılık, Zorunlu Uzaktan Ĕ̆itim, Uygulamalı Dersler. 


\title{
An Evaluation Regarding the Conducting of Applied Photography Courses via Distance Education
}

\begin{abstract}
During the COVID-19 pandemic, many applied courses along with theoretical courses had to be given through distance education. When the literature regarding the teaching of an applied course through distance education is examined, it is seen that the problems are experienced due to the theoretical emphasis of the applied courses through distance education and that it affects student performance negatively. The aim of this study is to examine and evaluate student perceptions about conducting photography lessons in formal education at undergraduate level in the communication faculties through distance education during the pandemic process. Mixed explanatory design was used in the study. The photography lesson was taught online for 14 weeks, then a 10-question questionnaire consisting of open and closed-ended questions was developed by the researcher and applied online to the students at the end of the fall semester of the 2020-2021 academic year. The sample of the study consists of 120 undergraduate students studying at the Faculty of Communication of Uşak University. Quantitative and qualitative data obtained from students were analysed and reported. As a result of the research, students were generally not satisfied with the distance education of the applied photography lessons, they thought that it had a negative effect on their learning performance, they thought that the theoretical parts of the courses were efficient, they thought the applied parts of the courses were inefficient, they found the use of materials in online courses useful, and the practical courses were distant education. It has reached the results that they do not want to be carried out through. It is suggested that the theoretical parts of the applied photography courses can be given through distance education, and the applied parts should be done face to face.
\end{abstract}

Keywords: Photography Course, Distance Education, Applied Photography Course, Compulsory Distance Education, Practical Lessons. 


\section{Giriş}

Olağan hayat akışımıza bir anda etki eden ve eğitsel bağlamda birçok uygulama ve teoriyi yeniden değerlendirmemize neden olan COVID-19 pandemi süreci, tüm dünyada hayatın her alanını etkilediği gibi eğitim-öğretim süreçlerini de etkilemiştir. Hastalığın salgın yayılım hızını azaltmak amacıyla özelden kamu sektörüne, eğitimden sanayi sektörüne kadar her kurumda önleyici önemler alınmaya başlamıştır. Türkiye'de Yükseköğretim Kurumu da (YÖK) salgın hastalığın yayılımını kontrol altına alabilmek amaciyla Mart 2020 döneminde yükseköğretim kurumlarında yüz yüze örgün öğretim yerine uzaktan öğretimin uygulanması yönünde karar almıştır. Bu kararla beraber yüz yüze yürütülmekte olan hem uygulamalı hem de kuramsal dersler, eğitim teknolojileri vasıtasıyla uzaktan eğitim yoluyla yürütülmeye başlanmıştır.

Uzaktan eğitimin temel amaçlarından biri şüphesiz, fiziksel uzaklıkları çeşitli aracılar sayesinde azaltmaktır (Simonson ve Schlosser, 2010). Uzaktan eğitim, eşzamanlı ve eş-zamansız eğitim teknolojileri aracılığıyla öğrenen - öğreten ve içerik arası etkileşimleri sağlayarak öğretim faaliyetlerinin yürütümünü amaçlamaktadır. Pandemi süreci ile uygulamalı dersler de bu teknolojiler aracılığı ile uzaktan yürütülmeye başlanmıştır. Uygulamalı dersler, herhangi bir konuya, deneysel, klinik ya da fiziksel uygulama yapmayı gerektiren derslerdir. Bu derslerde öğretim elemanı tarafından bir sürecin uygulamalı olarak gösterimi söz konusu olabildiği gibi, herhangi bir cihaz, alet ya da teknolojinin kullanımı ya da uygulanmasına yönelik iş ve işlemlerin yürütümü de söz konusu olabilmektedir.

Uygulamalı derslerde kuramsal bilgi ile deneyimin yansıtıcı bir süreç sonunda harmanlanarak öğrenmenin gerçekleşmesi beklenir (Torrens University, 2018). İletişim fakültelerinin gazetecilik, radyo televizyon ve sinema, yeni medya gibi bölümlerinde okutulmakta olan uygulamalı derslerden bazıları; kamera çekim ve aydınlatma teknikleri, kurgu, film yapım ve yönetimi ile fotoğrafçılık dersleridir. Bu dersler, alana özgü belirli bir kuramsal eğitimin yanında konuya ve derse özgü uygulamaları da içermektedir. İletişim fakültelerinde çoğu bölüm için ortak uygulamalı derslerden biri de fotoğrafçılık dersidir. İletişim fakülteleri bünyesinde fotoğrafçllık dersi gazetecilik, radyo televizyon ve sinema ve yeni medya gibi bölümlerde okutulmaktadır. 
Fotoğraf sanatı, küresel niteliğe sahip, bireylerin ve toplumların gayret, teknik ve imkanlarıyla şekillenerek evrimleşmiş, optik teknolojilerinin olanakları ile gelişmeye devam eden bir anlatım biçimi olarak karşımıza çıkmaktadır (Bulut ve Zor, 2020). Yükseköğretimde bu görsel anlatım biçiminin; fotoğrafçlık, temel fotoğrafçılık, uygulamalı fotoğrafçılık, temel fotoğrafçılık uygulamaları gibi isimlendirmelerle akademik öğretimi gerçekleştirilmektedir.

Fotoğrafçlık dersi, günümüz dijital teknolojilerin gelişmesiyle popülerliği artan hem seçmeli hem de zorunlu olabilen derslerden biridir (Zhou ve Guo, 2018). Fotoğrafçllık dersi, fotoğrafçılık uygulamaları ile ilgili temel beceri geliştirme, kuramsal fotoğraf bilgisi, ekipman bilgisi, çekim teknikleri, dijital düzenleme ve manipülasyon öğretimini de içeren bir derstir. Bu ders, fotoğraf ve fotoğraf sanatının ne olduğuyla ilgili kuramsal bilgi ile ışığın kullanımı, lens (objektif), flaş, tripod (üçayak) gibi aksesuarlar, kameralar, filtreler, farklı koşullarda çekim gerçekleştirme, çekilen görüntüleri işleme gibi temel uygulamalı konu başlıklarını da içermektedir (Langford, 2000; Rojprasert, Neanchaleay, Boonlue, ve Sinlarat, 2020). Fotoğrafçılık dersleri, Bloom taksonomisinde yer alan bilişsel, psikomotor ve duyuşsal öğrenme alanlarını içerir. Bu bağlamda, fotoğrafçılık dersleri anlama, analiz, değerlendirme ve yaratma bilişsel süreçleri ile algılama, beceri geliştirme psikomotor yetkinlikleri ve yapma, düzenleme, katılma, paylaşma gibi duyuşsal yetkinlikleri de içerir (Çubukçu, Ergeç, ve Gündüz, 2017). Öğrenme alan yetkinlikleri yanında, öğrencilerin estetik yeteneklerini ve sanatsal başarılarını geliştirebilir (Zhou ve Guo, 2018). Fotoğrafçılık dersleri, Uşak Üniversitesi İletişim Fakültesinde yüz yüze örgün öğretimde kuramsal ve uygulamalı bir şekilde işlenmektedir. Örgün öğretimde, sınıf ortamında gerçekleştirilen kuramsal öğretimle beraber, sınıf içi ve sınıf dışında uygulamalı fotoğraf çekim süreçlerini de içermektedir.

COVID-19 pandemi süreci ile beraber, T.C. Yükseköğretim Kurulu Başkanlığı birtakım kararlar almaya ve bunları uygulamaya başlamıştır. Bu kararlardan biri de salgının yayılma hızını düşürmek için yüz yüze etkileşimi azaltmak ve uzaktan eğitime geçiş yapmak olmuştur. Bu noktada Yükseköğretim Kurulu Başkanlığı, uygulamalı derslerin kuramsal kısımlarının uzaktan eğitim yoluyla yürütülebileceğini (Yükseköğretim Ku- 
rulu, 2020) belirtmiştir. Türkiye'de ve dünyada birçok yükseköğretim kurumu da hem kuramsal hem de uygulamalı derslerini uzaktan eğitim yoluyla yürütmeye başlamışlardır. Bazı yükseköğretim kurumları ise tıp, diş hekimliği, hemşirelik, spor bilimleri gibi uygulamalı derslerin yoğun olduğu programlarında seyreltilmiş yüz yüze ve hibrit öğretim faaliyetlerini gerçekleştirmeyi tercih etmişlerdir.

YÖK Yürütme Kurulu 2020 yılı Mayıs ayında aldıkları kararla Türkiye'de yükseköğretimde uzaktan eğitim yoluyla verilebilecek ders oranını \%40'a yükseltmişlerdir (YÖK, 2020). Bu bağlamda zorunlu uzaktan eğitim süreci sona erdikten sonraki süreçlerde uzaktan eğitim yoluyla öğretimi gerçekleştirilecek ders sayısında artış olacağı öngörülmektedir. Derslerin içeriği ve öğretim biçimleri ele alındığında, özellikle uygulamalı derslerin uzaktan eğitim yoluyla yürütümüne ilişkin olarak derinlemesine araştırma çalışmalarının gerekliliği ortaya çıkmıştır.

Yükseköğretimde, iletişim fakülteleri bünyesinde yüz yüze yürütülmekte olan fotoğrafçılık dersleri ise iletişim fakültelerinin tüm bölümleri itibariyle uzaktan öğretim yoluyla yürütülmesi kararı alındığı için uzaktan eğitim yoluyla yürütülmeye başlanmıştır. Hem öğretim elemanları hem de öğrenciler, uygulamalı olarak işlenmesi gereken bir dersi uzaktan eğitim teknolojileri vasitasıyla, sanal sınıflar üzerinden senkron ve asenkron olarak öğretimini gerçekleştirmeye başlamışlardır.

Uzaktan eğitim, doğası gereği birtakım sınırlılıkları olan yaklaşımlardan biridir. Bunlardan biri de öğrenen ve öğretici arasındaki mesafeden dolayı olan etkileşim sınırlılığıdır. Basantia (2018) uygulamalı derslerin uzaktan eğitim yoluyla yürütülmesinin zorlu bir süreç olduğunu, uygulamalı derslerin doğası gereği bir takım pratik ve fiziksel alıştırmalar içerdiğini belirtmiştir. Ağır (2007) ise uzaktan eğitim yoluyla gerçekleştirilen öğretimde, sosyalleşme konusunda sınırlılıklar olduğu için özellikle uygulama gerektiren derslerde öğrencilerin motivasyonlarında ve öğrenme performanslarında düşüşlere neden olabileceğini vurgulamıştır. Yılmaz (2020) uygulamalı dersler için uzaktan eğitim sistemlerinde güncelleme yapılmasını ya da uygulamalı derslerin uzaktan eğitimle yürütülebilmesine ilişkin alternatif yöntemlere ihtiyaç olduğuna dikkat çekmiştir.

Fojtík (2018) uygulama içeren derslerin uzaktan eğitim veya yüz yüze örgün şekilde alınması ile ilgili bir karşılaştırma yapmıştır. Uygulamalı dersleri uzaktan eğitim yoluyla alan öğrencilerin, akademik performans 
açısından daha başarısız olduklarını, yüz yüze uygulamalı eğitimde ise daha başarılı olduklarını belirtmiştir. Kahraman (2020) uygulamalı derslerin özellikle uzaktan eğitimle yürütülmesinde öğrencilerin çeşitli zorluklarla karşılaştığını, uygulamalı laboratuvar, atölye ya da stüdyo içerikli derslerin uzaktan eğitimle işlenmesinden dolayı öğrenme veriminin düştügünü belirtmiştir. Kürtüncü ve Kurt (2020) ise uygulamalı derslerin uzaktan eğitim yoluyla verilmesinin yetersiz olduğunu, yüz yüze etkileşimin olmamasının, imkanların kısıtlı olmasının ve uzaktan eğitim sistemindeki teknik sorunların, öğrencileri olumsuz yönde etkilediğini ve kaygılarını artırdığını belirtmişlerdir. Çözüm önerisi olarak da uygulamalı derslerin uzaktan eğitim yerine yüz yüze örgün şekilde ilerleyen dönemlerde tekrar edilmesini önermişlerdir. Özyürek, Begde, Yavuz ve Özkan (2016) yaptıkları çalışmada, araştırmaya katılan öğrencilerin uzaktan eğitimle yürütülen uygulamalı derslerin, uzaktan eğitim yerine yüz yüze örgün öğrenim olarak gerçekleştirilmesini istediklerini belirtmişlerdir. Yaman (2009) öğrencilerin gözünde özellikle fiziksel uygulama içeren uygulamalı derslerin, uzaktan eğitimle yürütülmesinin imkânsız olduğunu belirtmiştir. Yolcu (2020) yaptığı araştırmada, öğrencilerin uzaktan eğitimde iletişim problemleri yaşadıklarını ve özellikle de uygulamalı dersler için uzaktan eğitim yönteminin uygun olmadığını vurgulamışlardır. Basantia (2018) ise teori temelli dersler ile uygulamaya dayalı dersler arasındaki öğretimsel farkın, gerekli altyapı, finansal destek ve multimedya imkanlarının sağlanarak kapatılabileceğini belirtmiştir.

İlgili alanyazın taraması neticesinde, uygulamalı derslerin uzaktan eğitim yoluyla yürütülmesinde çeşitli zorluklar olabileceği, öğrencilerin performanslarını olumsuz yönde etkileyebileceği çıkarımlarında bulunulmuştur. Bu noktadan hareketle, pandemi sürecinde uzaktan eğitim yoluyla verilmek zorunda kalınan uygulamalı derslerden biri olan fotoğrafçılık derslerine ilişkin var olan durumun öğrencilerin bakış açılarıyla yani kendi algılarıyla betimlenmesi gerekliliği ortaya çıkmıştır.

$\mathrm{Bu}$ araştırmada, Uşak Üniversitesi İletişim Fakültesinde lisans düzeyinde örgün öğretimde kuramsal ve uygulamalı olarak yüz yüze yürütülmekte olan fotoğrafçılık derslerinin, pandemi sürecinde uzaktan eğitim yoluyla yürütülmesine ilişkin öğrenci görüşleri incelenerek var olan durumun raporlanması yapılmıştır. 
Öğrencilerin uygulamalı bir dersin uzaktan eğitim yoluyla yürütülmesine ilişkin, öğrenci algıları anketinden elde edilen nicel veriler ile öğrenci görüşlerinden elde edilen nitel veriler incelenerek;

- Genel memnuniyet düzeyleri nedir?

- Memnuniyet düzeyleri cinsiyete göre farklılaşmakta mıdır?

- Memnuniyet düzeyleri öğrenim durumlarına göre farklılaşmakta m1dir?

- Kuramsal boyutuna ilişkin memnuniyet düzeyleri nedir?

- Uygulamalı boyutuna ilişkin memnuniyet düzeyleri nedir?

- Zorunlu uzaktan eğitim sürecine ilişkin görüşleri nelerdir? sorularının cevapları aranmıştır.

Böylece uygulamalı bir dersin uzaktan eğitimle yürütülmesine ilişkin öğrencilerin algıları ortaya konarak uygulamalı derslerin uzaktan eğitim yoluyla öğretim sürecine ilişkin hem akademisyenlere hem de karar vericilere yönelik uygulama önerileri sunulmuştur.

\section{Yöntem}

$\mathrm{Bu}$ araştırmanın modeli, karma açılayıcı desendir (Cresswell ve Clark, 2007). Bu yöntemde öncelikle nicel veriler toplanıp analiz edilir, ardından bu elde edilen verilerin tamamlanması ve rafine edilebilmesi amaciyla nitel veri toplama işlemi gerçekleştirilir (Büyüköztürk, Çakmak, Akgün, Karadeniz ve Demirel, 2013). Verilerin bütünlüğünün sağlanması ve daha somut çıkarımlar elde edilebilmesi amacıyla karma açıklayıcı desen kullanımı tercih edilmiştir. Öğrencilerin var olan durumları, olduğu şekilde betimlenmeye çalışılmış ve toplanan nicel verilerin nitel verilerle desteklenmesi amaçlanmıştır.

\section{Örneklem}

Araştırmanın örneklemini, 2020-2021 öğretim yılı güz döneminde Uşak Üniversitesi, İletişim Fakültesinde öğrenimlerini gerçekleştirmekte olan, Radyo Televizyon ve Sinema bölümü ile Yeni Medya bölümü birinci ve ikinci öğretim öğrencilerinden oluşan ve uzaktan eğitim yoluyla fotoğrafçılık dersini alan toplam 239 öğrenciden kendilerine çevrimiçi iletilen an- 
keti yanıtlayarak araştırmaya gönüllü olarak katılmayı beyan eden 120 öğrenci, araştırmanın nicel boyutunun örneklemini oluşturmaktadır. Aynı öğrenci grubundan kendilerine çevrimiçi iletilen görüşme formlarını yanıtlayan 64 öğrenci ise araştırmanın nitel boyutunun örneklemini oluşturmaktadır. Öğrencilerin bölümlere göre dağılımları Tablo 1'de sunulmuştur.

Tablo 1. Öğrencilerin Bölümlerine Göre Dağılımları

\begin{tabular}{llll}
\hline Bölüm & Sınıf & Öğrenci Sayısı & \% \\
\hline Radyo TV Sinema & 3 & 26 & 21.67 \\
Radyo TV Sinema (İ.Ö.) & 3 & 21 & 17.50 \\
Yeni Medya & 2 & 36 & 30.00 \\
Yeni Medya (İ.Ö.) & 2 & 37 & 30.83 \\
Toplam & - & $\mathbf{1 2 0}$ & $\mathbf{1 0 0}$ \\
\hline
\end{tabular}

\section{Veri Toplama Araçları ve Analizi}

Araştırmada veri toplama aracı olarak, araştırmacı tarafından geliştirilen, uygulamalı fotoğrafçılık dersinin uzaktan eğitim yoluyla yürütülmesine ilişkin öğrenci algısı anketi kullanılmıştır. Anketin ilk bölümünde öğrencilerin kişisel demografik bilgileri (ör: cinsiyet, sınıf vb.) toplanmıştır. İlgili anket 10 tane beşli likert tipi soru içermektedir. Anket maddeleri, uzaktan eğitim yoluyla uygulanan fotoğrafçllık dersini kapsamaktadır. Anketin kapsam geçerlik çalışmaları kapsamında, iki alan uzmanı tarafından maddeler incelenip, son biçimini almıştır. Anket seçenekleri ise, 1 hiç katılmıyorum, 2 katılmıyorum, 3 kararsızım, 4 katılıyorum, 5 kesinlikle katılıyorum şeklindedir. Anketten elde edilen nicel veriler betimsel olarak analiz edilmiştir.

Anket maddeleri şu şekildedir;

1. Fotoğrafçlık dersinin uzaktan eğitim yoluyla işlenmesinden memnunum.

2. Uzaktan eğitim yoluyla işlenen fotoğrafçılık dersi verimliydi.

3. Uzaktan eğitim yoluyla işlenen fotoğrafçılık derslerinin kuramsal kısımları verimliydi.

4. Uzaktan eğitim yoluyla işlenen fotoğrafçılık derslerinin uygulamalı pratik kısımları verimliydi.

5. Uzaktan eğitim yoluyla işlenen fotoğrafçıllk dersi sayesinde iyi fotoğraflar çekebileceğimi düşünüyorum. 
6. Uzaktan eğitim yoluyla işlenen fotoğrafçlık dersi sayesinde farklı fotoğraf çekim tekniklerini kendim uygulayabilirim.

7. Bu dersi uzaktan işleyerek daha iyi öğrendiğimi düşünüyorum.

8. Kaçırdığım derslerin videolarını sonradan izleyebilmek faydalıydı.

9. Sağlanan ders materyalleri (Örn. PowerPoint sunumlar) benim için faydalıyd.

10. İlerleyen dönemlerde de bu tür uygulamalı derslerimin uzaktan eğitim yoluyla yürütülmesini isterim.

Araştırmada, anketten elde edilen nicel verilerden daha derinlemesine değerlendirmede bulunabilmek amacıyla yarı yapılandırılmış görüşme formu aracılığıyla öğrencilerin görüş ve önerilerini içeren nitel veriler toplanmıştır. Nitel veri toplama sürecinde öğrencilere iki adet açık uçlu soru yöneltilmiştir. Öğrencilere,

1. (Açık uçlu) Uygulamalı bir dersin uzaktan eğitim yoluyla işlenmesini nasıl değerlendiriyorsunuz? Görüşünüz nedir?

2. (Açık uçlu) Sizce pandemi sürecinde uygulamalı bir ders nasıl işlenmesi gerekirdi? Öneriniz nedir?

soruları çevrimiçi olarak yöneltilmiş ve öğrencilerin yazılı olarak görüşlerini iletmeleri sağlanmıştır.

Verilerin analizi sürecinde nicel veriler SPSS programı aracılığıyla incelenmiştir. Parametrik analizler öncesi verilerin uygunluğu açısından incelemeler yapılmıştır. Anket puan aralıkları Tekin (1991) tarafından belirtilen 4.20-5.00 kesinlikle katıliyorum, 3.40-4.19 katılıyorum, 2.60-3.39 kısmen katıliyorum, 1.80-2.59 katılmıyorum, 1.00-1.79 kesinlikle katılmıyorum şeklinde derecelendirilmiştir.

Öğrencilerin açık uçlu sorulara verdikleri yazılı yanıtlar ise içerik analizi ile incelenmiştir. İçerik analizi, elde edilen nitel verilerden sistematik, geçerli ve kapsamlı çıkarımlarda bulunabilmek kullanılan bir tekniktir. Böylece nesnel sonuçların elde edilmesi amaçlanmıştır (Krippendorff, 2004). Bu bağlamda öğrenci mesajları iki alan uzmanı tarafından incelenerek, oluşturulan tema ve kategorilere dağıtımı yapılmıştır. Kodlamayı gerçekleştiren uzmanlar arasındaki uyum, Cohen's Kappa istatistiği ile test edilip raporlanmıştır. Landis ve Koch, (1977) puanlayıcılar arası uzlaşma oranlarını 0.01 - 0.20 arasında çok küçük uyum, 0.21 - 0.40 küçük uyum, 0.41 - 0.60 orta düzeyde uyum, 0.61 - 0.80 iyi düzeyde uyum, $0.81-1.00$ 
mükemmel düzeyde uyum olarak derecelendirmişlerdir. Yapılan kodlama sonucu elde edilen bulgular, yüzde ve frekans tabloları halinde betimsel olarak raporlanmıştır.

\section{Uygulama Süreci}

Öğrenciler, 2020-2021 güz yarıyılında 14 hafta boyunca uzaktan eğitim yoluyla fotoğrafçlık derslerini işlemişlerdir. Bütün dersler, aynı öğretim elemanı tarafından, aynı ders içerikleri ile aynı kuramsal ve pratik uygulamalarla işlenmiştir. Öğrenciler asenkron derslerine Moodle öğrenme yönetim sistemi üzerinden erişmişlerdir ve senkron derslerine de BigBlueButton sanal sınıf yazılımı üzerinden erişim sağlamışlardır. 14 haftalık dönem sona erdiğinde çevrimiçi olarak anket uygulaması ve nitel görüşme verisi toplama işlemi gerçekleştirilmiştir.

\section{Bulgular}

Araştırmanın bu bölümünde, anketten elde edilen nicel ve nitel verilerin analizi sonucu elde edilen bulgular raporlanmıştır.

\section{Öğrenci Grubuna İlişkin Betimsel Bulgular}

Araştırmaya katılan 120 öğrencinin cinsiyetlerine göre dağılımları Tablo 2'deki gibidir.

Tablo 2. Öğrencilerin Cinsiyetlerine Göre Dağılımları

\begin{tabular}{lll}
\hline Cinsiyet & f & \% \\
\hline Kadın & 56 & 46.7 \\
Erkek & 64 & 53.3 \\
Toplam & $\mathbf{1 2 0}$ & $\mathbf{1 0 0}$ \\
\hline
\end{tabular}

Araştırmaya katılan 120 öğrencinin \%46.7'si (N:56) kadın \%53.3's1 (N:64) ise erkek öğrencilerden oluşmaktadır. Öğrenciler öğrenim durumlarına göre incelendiklerinde ise, \%51.7' si (N:62) birinci öğretim öğrencisi iken, \%48.3'ü (N:58) ise ikinci öğretim öğrencisidir. Birinci öğretim öğrencilerinin sayısının bir miktar yüksek olduğu ifade edilebilir. 


\section{Uzaktan Eğitim Yoluyla İşlenen Fotoğrafçılık Dersine İlişkin Öğrenci Algıları Anketi Bulguları}

Anketten elde edilen bulgular Tablo 3'de sunulmuştur. Öğrencilerin anket maddelerine verdikleri yantların ortalama, standart sapma değerleri verilmiştir.

Tablo 3. Uygulamalı Fotoğrafçılık Dersinin Uzaktan Eğitim Yoluyla Yürütülmesine İlişkin Öğrenci Algılarn Anketi

\begin{tabular}{|c|c|c|c|c|c|}
\hline & Anket Maddesi & $X^{-}$ & SS & $N$ & Genel Düzey \\
\hline 1 & $\begin{array}{l}\text { Fotoğrafçllık dersinin uzaktan eğitim yo- } \\
\text { luyla işlenmesinden memnunum. }\end{array}$ & 2.29 & 1.312 & 120 & Katılmiyorum \\
\hline 2 & $\begin{array}{l}\text { Uzaktan eğitim yoluyla işlenen fotoğrafçı- } \\
\text { lık dersi verimliydi. }\end{array}$ & 3.17 & 1.349 & 120 & $\begin{array}{l}\text { Kismen katıliyo- } \\
\text { rum }\end{array}$ \\
\hline 3 & $\begin{array}{l}\text { Uzaktan eğitim yoluyla işlenen fotoğrafçı- } \\
\text { lık derslerinin kuramsal kısımları verim- } \\
\text { liydi. }\end{array}$ & 3.59 & 1.293 & 120 & Kat1lyyorum \\
\hline 4 & $\begin{array}{l}\text { Uzaktan eğitim yoluyla işlenen fotoğrafçı- } \\
\text { lık derslerinin uygulamal pratik kısımları } \\
\text { verimliydi. }\end{array}$ & 2.49 & 1.250 & 120 & Katılmiyorum \\
\hline 5 & $\begin{array}{l}\text { Uzaktan eğitim yoluyla işlenen fotoğrafçı- } \\
\text { lık dersi sayesinde iyi fotoğraflar çekebile- } \\
\text { ceğimi düşünüyorum. }\end{array}$ & 2.88 & 1.313 & 120 & $\begin{array}{l}\text { Kismen katiliyo- } \\
\text { rum }\end{array}$ \\
\hline 6 & $\begin{array}{l}\text { Uzaktan eğitim yoluyla işlenen fotoğrafçı- } \\
\text { lık dersi sayesinde farkl fotoğraf çekim tek } \\
\text { niklerini kendim uygulayabilirim. }\end{array}$ & -3.02 & 1.360 & 120 & $\begin{array}{l}\text { Kismen katiliyo- } \\
\text { rum }\end{array}$ \\
\hline 7 & $\begin{array}{l}\text { Bu dersi uzaktan işleyerek daha iyi öğren- } \\
\text { diğimi düşünüyorum. }\end{array}$ & 2.24 & 1.108 & 120 & Katılmiyorum \\
\hline 8 & $\begin{array}{l}\text { Kaçırdığım derslerin videolarını sonradan } \\
\text { izleyebilmek faydalıydı. }\end{array}$ & 3.88 & 1.199 & 120 & Katılıyorum \\
\hline 9 & $\begin{array}{l}\text { Sağlanan ders materyalleri (Örn. PowerPo- } \\
\text { int sunumlar) benim için faydalıydı. }\end{array}$ & 3.43 & 1.327 & 120 & Kattliyorum \\
\hline 10 & $\begin{array}{l}\text { derslerimin uzaktan eğitim yoluyla yürü- } \\
\text { tülmesini isterim. }\end{array}$ & 2.07 & 1.172 & 120 & Katılmiyorum \\
\hline & Toplam & 2.90 & 1.268 & 120 & - \\
\hline
\end{tabular}

Tablo 3'e göre, her bir anket maddesi detaylı olarak ele alınmıştır. Öğrencilerin fotoğrafçılık derslerinin uzaktan eğitim yoluyla işlenmesinden memnun olmadıkları ifade edilebilir (X: 2.29). İkinci madde olan uzaktan eğitim yoluyla işlenen fotoğrafçılık dersinin verimli olup olmadığıyla ilgili olarak öğrenciler, kısmen katıldıklarını belirtmişlerdir (X: 3.17). Bu bulgu öğrencilerin, uzaktan eğitim yoluyla işlenen fotoğrafçılık dersinin kısmen verimli buldukları şeklinde yorumlanmıştır. Üçüncü madde olan, 
uzaktan eğitim yoluyla işlenen fotoğrafçılık derslerinin kuramsal kısımları verimliydi anket maddesi için öğrenciler, katıldıklarını belirtmişlerdir (X: 3.59). Bu bulgu, öğrencilerin fotoğrafçılık dersine ilişkin sözlü, kuramsal konu anlatım bölümlerini verimli buldukları şeklinde yorumlanmıştır. Dördüncü madde olan, uzaktan eğitim yoluyla işlenen fotoğrafçılık derslerinin uygulamalı pratik kısımları verimliydi anket maddesi için öğrenciler katılmadıklarını belirtmişlerdir (X: 2.49). Bu bulgu, öğrencilerin uzaktan eğitim yoluyla yürütülen fotoğrafçlık dersine ilişkin uygulama ve pratik yapma konusunda verimli bulmadıkları şeklinde yorumlanmıştır. Bu bulgu sonuçlar bölümünde detaylı şekilde ele alınıp tartışılmıştır.

Beşinci madde olan, uzaktan eğitim yoluyla işlenen fotoğrafçılık dersi sayesinde iyi fotoğraflar çekebileceğimi düşünüyorum anket maddesi için öğrenciler, kısmen katıldıklarını belirtmişlerdir (X: 2.88). Altıncı madde olan uzaktan eğitim yoluyla işlenen fotoğrafçılık dersi sayesinde farklı fotoğraf çekim tekniklerini kendim uygulayabilirim anket maddesi için öğrenciler, kısmen katıldıklarını belirtmişlerdir (X: 3.02). Bu iki bulgunun öğrencilerin bu dersin ardından öğrendikleriyle ilgili uygulamaya geçiş noktasında öğrendikleri sayesinde iyi fotoğraf çekebileceklerinden tam emin olmadıkları, kararsızlık yaşadıkları şeklinde yorumlanmıştır. Yedinci madde olan -bu dersi uzaktan işleyerek daha iyi öğrendiğimi düşünüyorum anket maddesi için öğrenciler, katılmadıklarını belirtmişlerdir (X: 2.24). Bu bulgu, öğrencilerin uzaktan eğitim yoluyla yürütülen fotoğrafçılık dersine ilişkin öğrenme algılarının düşük olduğu şeklinde yorumlanmıştır. Sekizinci madde olan, kaçırdığım derslerin videolarını sonradan izleyebilmek faydalıydı anket maddesi için öğrenciler büyük oranda katıldıklarını belirtmişlerdir (X: 3.88). Moodle öğrenme yönetim sistemi üzerinden öğrencilerin BigBlueButton sanal sınıf sisteminin geçmiş ders video kayıtlarına erişebilme imkanları vardı. Dolayısıyla bu durumla ilgili algılarının olumlu olduğu ifade edilebilir. Dokuzuncu madde olan sağlanan ders materyalleri (Örn. PowerPoint sunumlar) benim için yeterliydi anket maddesi için öğrenciler, katıldıklarını belirtmişlerdir (X: 3.43). Araştırmada, tüm öğrenciler için 14 haftalık fotoğrafçlık ders içeriği Moodle ÖYS üzerinden öğrencilere sağlanmıştı. Dolayısıyla öğrencilerin bu materyallerin sağlanmasını öğrenmeleri için faydalı buldukları şeklinde yorumlanmıştır. Son anket maddesi olan -ilerleyen dönemlerde de bu tür 
uygulamalı derslerimin uzaktan eğitim yoluyla yürütülmesini isterim anket maddesi için öğrenciler en düşük puanı vermişlerdir ( $X: 2.07)$. Bu bulgu, öğrencilerin fotoğrafçılık dersi gibi uygulamalı derslerini uzaktan eğitim yoluyla almaya devam etmek istemedikleri şeklinde yorumlanmıştır.

Öğrencilerin uzaktan eğitim yoluyla işlenen fotoğrafçılık dersine ilişkin öğrenci anketinden elde edilen toplam puan ortalamalarının cinsiyete göre anlamlı bir farklılık gösterip göstermediği t-testi ile analiz edilmiştir. Anket toplam ortalama puan verilerinin parametrik analizlere uyguna olup olmadığ 1 incelenmiş ve verilerin uygun olduğu tespit edilerek t-testi gerçekleştirilmiştir. T-testi analiz sonuçları Tablo 4 'te sunulmuştur.

Tablo 4. Öğrencilerin Cinsiyetlerine Göre Uzaktan Ĕ̆itim Yoluyla Yürütülen Fotoğrafçılık Dersine İlişkin Toplam Anket T-Testi Karşılaştırma Analiz Sonuçları

\begin{tabular}{lllllll}
\hline Cinsiyet & $\mathbf{N}$ & $\mathbf{X}$ & SS & Sd & t & p \\
\hline Kadın & 56 & 2.844 & .799 & 118 & -.740 & .376 \\
Erkek & 64 & 2.957 & .865 & & & \\
\hline
\end{tabular}

Tablo 4'te yer alan t-testi sonuçları doğrultusunda cinsiyete göre toplam anket ortalama puanları üzerinden bir farklılık bulunmamıştır. Bir başka deyişle öğrencilerin uzaktan eğitim yoluyla yürütülen fotoğrafçılık dersine ilişkin alg1 düzeyleri, cinsiyetlerine göre farklılık göstermemekte$\operatorname{dir}[\mathrm{t}(118)=-.740, \mathrm{p}>.05]$. Benzer şekilde, öğrencilerin birinci öğretim ya da ikinci öğretim olma durumlarına göre de anket toplam puanları arasında bir farklılık bulunmamaktadır [t(118)=.325, p>.05].

Uzaktan eğitim yoluyla yürütülen fotoğrafçılık dersine ilişkin öğrencilerin, kuramsal (X: 3.59) ve uygulamalı (X: 2.49) kısımlara ilişkin anket puan ortalamalarının arasındaki fark karşılaştırılmıştır. T-testi analiz sonuçları Tablo 5'te sunulmuştur.

Tablo 5. Uzaktan Ĕ̆itim Yoluyla Yürütülen Fotoğrafçılık Dersine İlişkin Kuramsal ve Uygulama Toplam Anket Puan Ortalamalarının T-Testi ile Karşılaştırmasına İlişkin Analiz Sonuçları

\begin{tabular}{lllllll}
\hline Dersin Bölümleri & $\boldsymbol{N}$ & $\boldsymbol{X}^{-}$ & $S S$ & $S \boldsymbol{t}$ & $\boldsymbol{t}$ & $\boldsymbol{p}$ \\
\hline Kuramsal kisim & 120 & 3.59 & 1.293 & 119 & 30.426 & .000 \\
Uygulamalı kısım & 120 & 2.49 & 1.250 & & & \\
\hline
\end{tabular}


Tablo 5 'te yer alan t-testi sonuçlarına göre uzaktan eğitim yoluyla yürütülen fotoğrafçlık dersinin kuramsal konu anlatım bölümlerine ilişkin öğrencilerin verimlilik algıları, uygulamalı konu anlatım bölümlerine ilişkin öğrencilerin verimlilik algıları arasında anlamlı farklılık vardır. Bu bulgu, öğrencilerin uzaktan eğitim yoluyla kuramsal konu anlatımını verimli buldukları, dersin uygulamalı kısımlarını verimli bulmadıkları şeklinde yorumlanmıştır.

\section{Öğrenci Mesajlarının Nitel Analizine İlişkin Bulgular}

Öğrencilere, uygulamalı bir dersin uzaktan eğitim yoluyla işlenmesini nasıl değerlendiriyorsunuz (görüş̧) ve uygulamah bir dersin uzaktan eğitim yoluyla nasıl işlenmesi gerekirdi (öneri) şeklinde iki adet açık uçlu soru yöneltilmiştir. Yarı yapılandırılmış çevrimiçi görüşme formlarını, anketi yanıtlayan 120 öğrenciden 64 'ü yanıtlamıştır. Öğrencilerin görüşme formlarındaki sorulara verdikleri yanıtların küme dağılımı Şekil-1'deki gibi oluşmuştur.

Görüş

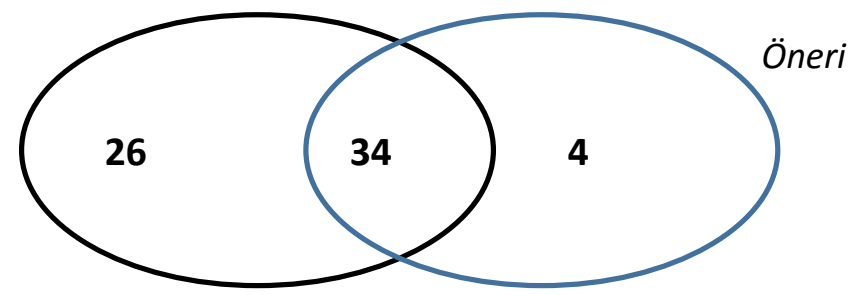

Şekil 1. Öğrencilerden Toplanan Nitel Veriler ve Dă̆ılımları

Görüşme formlarındaki iki adet açık uçlu (görüş, öneri) soruyu yanıtlayan toplam 64 öğrenciden bazı öğrenciler yalnızca görüş (N:26), bazıları yalnızca öneri (N:4) iletirlerken, bazıları da hem görüş hem de öneri $(\mathrm{N}: 34,34)$ olmak üzere toplam 98 yanit (60 görüş + 38 öneri) iletmişlerdir. Uygulamalı bir dersin uzaktan eğitim yoluyla yürütülmesine ilişkin öğrenci değerlendirmeleri, görüş teması altında kodlanmıştır. Uygulamalı bir dersin uzaktan eğitim yoluyla nasıl yürütülmesi gerektiğine ilişkin öğrenci önerileri de öneri teması altında kodlanmıştır. Her bir temanın altında, Holsti (1969) ve Gökçe (2006)'nin önerdiği ayırt edici, farklılı̆̆ı ortaya koyucu, bütünsel, objektif, araştırmanın amacına uygun, kapsayıcı nitelikte kategoriler oluşturulmaya dikkat edilmiştir. Kodlayıcılar arası uyum, iki ana 
tema altında yazılan görüş ve öneriler için ayrı ayrı ele alınmıştır. Görüş ana teması (5 kategori) altına gönderilen 60 adet mesajın incelenmesi neticesinde iki kodlayıcı arasında $\kappa=.830(\mathrm{p}<.05)$ mükemmel düzeyde uyum olduğu bulgusuna ulaşılmıştır. Öneri ana teması (5 kategori) altına gönderilen 38 adet mesajin incelenmesi neticesinde iki kodlayıcı arasında $\kappa=.789(\mathrm{p}<.05)$ iyi düzeyde uyum olduğu bulgusuna ulaşılmıştır. Öğrenci görüşlerinin kategorilere dağılımı Tablo 6'daki gibi olmuştur.

Tablo 6. Öğrenci Görüşleri İçerik Analizi Betimsel İstatistikleri

\begin{tabular}{|c|c|c|c|c|}
\hline Ana Tema & Görüş Sayısı & Kategoriler & $\mathbf{f}$ & $\%$ \\
\hline \multirow[t]{5}{*}{ Görüş } & 60 & Verimli değildi & 28 & 46.7 \\
\hline & & Nitelikli uygulama yapılamadı & 12 & 20.0 \\
\hline & & Süreçte zorlandım & 8 & 13.3 \\
\hline & & Kalıcı öğrenme gerçekleştiremedim & 6 & 10.0 \\
\hline & & Süreçten memnun kaldım & 6 & 10.0 \\
\hline \multirow[t]{5}{*}{ Öneri } & 38 & $\begin{array}{l}\text { Kuramsal kısımlar uzaktan eğitim ile, uygulamalı kısımlar ise } \\
\text { yüz yüze yapılmalı (Hibrit öğretim) }\end{array}$ & $\mathrm{e}_{18}$ & 47.4 \\
\hline & & $\begin{array}{l}\text { Uygulamalı dersler uzaktan eğitimle yapılmamalı, bir sonrak } \\
\text { döneme bırakılmalı }\end{array}$ & $\mathrm{i}_{8}$ & 21.1 \\
\hline & & Uzaktan eğitim yoluyla daha fazla uygulama yapılmalı & 4 & 10.5 \\
\hline & & Uzaktan eğitimde daha fazla ders materyali sağlanmalı & 4 & 10.5 \\
\hline & & Bu şekilde uzaktan eğitim devam etmeli & 4 & 10.5 \\
\hline
\end{tabular}

Öğrencilerden gelen tüm görüş ve öneri mesajlarına yapılan içerik analizi sürecinde toplam 98 mesaj incelenmiştir. Görüş ileten 60 öğrencinin \%46.7'si (f:28) uzaktan eğitim yoluyla yürütülen uygulamalı fotoğrafçılık dersinin verimli olmadığı görüşüne sahip oldukları bulgusuna ulaşılmıştır. Araştırmanın nicel bölümünde birinci anket sorusundan elde edilen dersin uzaktan eğitim yoluyla işlenmesinden memnun olmadıklarını belirten öğrenci görüşlerini destekleyici nitelikte bulgu olduğu söylenebilir.

Bu bulgu ile birlikte, uzaktan eğitim nedeniyle nitelikli uygulama gerçekleştirilemediğini belirten öğrencilerin oranı ise \%20 (f:12) şeklinde gerçekleşmiştir. Bu yönde görüş bildiren öğrenciler hem kuramsal hem de uygulamaya dayalı bir ders olan fotoğrafçılık dersinin uzaktan eğitim ile işlenmesinden kaynaklı uygulamaların nitelikli olmadığını belirttikleri söylenebilir. Araştırmanın nicel bölümünde öğrenciler -uzaktan eğitim dersin uygulamalı kısımlarını kuramsal kısma göre anlamlı olarak daha az verimli olduğuna ilişkin bulgusuyla bu bulgunun örtüştüğü ifade edilebilir. 
Uzaktan eğitim süreçleri nedeniyle internet, cihaz, erişim vb. durumlardan dolayı zorlandıklarını belirten öğrencilerin oranı ise \%13.3 (f:8) olduğu söylenebilir. Öğrencilerin \%10'u (f:6) ise uzaktan eğitim yoluyla gerçekleştirilen fotoğrafçılık dersinde kalıcı öğrenme gerçekleştiremediklerini düşünmektedirler. Tüm bu görüşlerle beraber, görüş bildiren öğrencilerin \%10'u (f:6) pandemi sürecinde uygulamalı bir dersin uzaktan eğitim yoluyla gerçekleştirilmesinden memnun oldukları bulgusuna erişilmiştir. Uzaktan eğitim sürecinden memnun olan öğrenciler, özellikle salgın ve sağlık koşulları nedeniyle bu şekilde bir uygulama yapılmasının uygun bulduklarını belirtmişlerdir.

Öneri ileten 38 öğrencinin hemen hemen yarısı \%47.4 (f:18) fotoğrafçılık dersinin kuramsal kısımlarının uzaktan eğitim ile, uygulamalı kısımlarının ise yüz yüze yapılması gerektiğini belirtmişlerdir. Bir başka ifade ile hibrit öğretim modelinin uygulanmasını önermişlerdir. Öğrencilerin \%21.1'i (f:8) ise uygulamalı derslerin uzaktan eğitimle yapılmamasını, pandemi süreci sona erdikten sonraki dönem yüz yüze yapılmasını önermişlerdir. Öneri ileten öğrencilerin \%10.5'i (f:4) ise uzaktan eğitim yoluyla işlenen fotoğrafçılık dersinde daha fazla uygulama yapılmasını önermişlerdir ayrıca öğrencilerin \%10.5'i (f:4) ise fotoğrafçılık dersi için daha fazla materyal (ders içeriği) sağlanması önerisinde bulunmuşlardır. Tüm bu önerilerle beraber ilerleyen dönemlerde de bu şekilde uzaktan eğitimin devam etmesini isteyen öğrencilerin oranı ise \%10.5 (f:4) şeklinde gerçekleşmiştir. Görüş ve önerilere ilişkin tüm nitel bulgular, sonuçlar bölümünde anketten elde edilen nicel verilerle birlikte karşılaştırılarak tartışılmiştır.

\section{Tartışma ve Sonuç}

$\mathrm{Bu}$ araştırmada, bir yükseköğretim kurumunda lisans düzeyinde örgün öğretimde kuramsal ve uygulamalı olarak yüz yüze yürütülmekte olan fotoğrafçılık derslerinin, pandemi sürecinde uzaktan eğitim yoluyla yürütülmesine ilişkin öğrenci algıları ve görüşleri incelenerek var olan durumun raporlanması yapılmıştır.

Araştırmaya 120 lisans öğrencisi katılmıştır. Öğrencilerin uzaktan eğitim yoluyla işlenen fotoğrafçılık dersine ilişkin kendilerine iletilen anket- 
ten elde edilen veriler neticesinde, anketin tamamı için öğrencilerin kısmen memnuniyet duydukları ve cinsiyetlerine göre ise görüşleri arasında erkekler lehine bir farklılık olsa da anlamlı bir farklılık olmadığı sonuçlarına ulaşılmıştır. Cinsiyet bakımından, Yalman (2013), Korkmaz (2016) ve Sel (2018) tarafından gerçekleştirilen araştırma bulguları itibariyle benzer paralellikte sonuçlar elde edildiği ifade edilebilir.

Ayrıca derslerin kuramsal konu anlatım bölümlerine ilişkin öğrencilerin verimlilik algıları ile dersin uygulamalı bölümlerine ilişkin öğrencilerin verimlilik algıları arasında anlamlı farklılık bulunmuş, öğrenciler uzaktan eğitim yoluyla kuramsal anlatımları verimli bulurken, uygulamalı kısımları ise verimsiz bulmuşlardır. Öğrencilerin nicel anket verileri madde bazlı ele alındığında ise,

- Uygulamalı fotoğrafçılık dersinin uzaktan eğitim yoluyla yürütülmesinden memnun olmadikları,

- Buna rağmen dersin kısmen verimli olduğunu düşündükleri,

- Uzaktan eğitim derslerinin özellikle de kuramsal kısımlarının verimli olduğunu düşündükleri,

- Uzaktan eğitim yoluyla işlenen fotoğrafçıllk dersinin uygulama-pratik kısımlarının verimli olmadığını düşündükleri,

- Bu derslerden sonra iyi fotoğraf çekebilecekleri konusuna kısmen katıldikları,

- Mesleki yaşamlarında farklı çekim tekniklerini uygulayabilme noktasında kısmen katıldıkları,

- Bu dersin uzaktan eğitim yoluyla işlenmesi nedeniyle iyi bir öğrenme süreci geçirmediklerini düşündükleri,

- Bunlara rağmen ders videolarının uzaktan eğitim sistemine kaydedilmesi ve daha sonradan bu kayıtların izlenebiliyor olmasını faydalı buldukları,

- Ders öğretim elemanı tarafından kendilerine iletilen sunu, Pdf, fotoğraf, görsel materyal vb. ders materyal ve içeriklerinin öğrenmeleri için faydalı bulduklarını,

- Ancak ilerleyen dönemlerde diğer uygulamalı derslerinin uzaktan eğitim yoluyla yürütülmesini istemedikleri sonuçlarına ulaşılmıştır.

Anketten elde edilen tüm bu araştırma bulguları ilgili alanyazın çerçevesinde ele alındığında, Kahraman (2020) ve Fojtík (2018) uygulamalı derslerin özellikle uzaktan eğitimle yürütülmesinde öğrencilerin çeşitli 
zorluklarla karşılaştığını, uygulamalı laboratuvar, atölye ya da stüdyo içerikli derslerin uzaktan eğitimle işlenmesinden dolayı öğrenme veriminin düştügünü belirtmişti. Kürtüncü ve Kurt (2020) ise uygulamalı derslerin uzaktan eğitim yoluyla verilmesinin yetersiz olduğunu, yüz yüze etkileşimin olmamasının, teknik imkanların kısıtlı olmasının ve uzaktan eğitim sistemindeki teknik sorunların öğrencileri olumsuz yönde etkilediğini ve kaygılarını artırdığını belirtmişlerdi. Basantia (2018) ise uygulamalı derslerin uzaktan eğitim yoluyla yürütülmesinin zorlu bir süreç olduğunu, uygulamalı derslerin doğası gereği bir takım pratik ve fiziksel alıştırmalar içerdiğini belirtmişti. Benzer şekilde Yolcu (2020) öğrencilerin uzaktan eğitimde iletişim problemleri yaşadıklarını ve özellikle de uygulamalı dersler için uzaktan eğitim yönteminin uygun olmadığını vurgulamıştır. $\mathrm{Bu}$ araştırma sonuçlarının, uygulamalı derslerin uzaktan eğitim yoluyla yürütülmesine ilişkin ilgili araştırma bulgularıyla benzer paralellik gösterdiği, öğrencilerin uygulamalı derslerin uzaktan eğitimle işlenmesini özellikle uygulama tabanlı dersler için verimli bulmadıkları ifade edilebilir. Uygulamalı bir dersin kuramsal kısmının uzaktan eğitim yoluyla verilmesinden genel bir memnuniyet durumu söz konusu olsa da pratik k1sımlarının uzaktan eğitimle yürütümü öğrencileri memnun etmediği sonuçlarına ulaşılmıştır.

Şekerci, Danacı, ve Elinç (2021) yaptıkları araştırmada, uygulamalı derslerde uzaktan eğitimin sürdürülebilirliğini mimarlık eğitimi çerçevesinde ele almışlardır. Günden güne dijitalleşen dünyamızda yüz yıla yakındır yüz yüze verilen uygulamalı mimarlık eğitimlerinin, uygun altyapı ve çevrimiçi araçlar sayesinde uzaktan eğitim yoluyla verilebileceğini belirtmişlerdir. Uygulamalı derslerin, gerektirdiği uygulama biçim ve yoğunluğuna göre uzaktan eğitim teknolojileri vasitasıyla yürütümü mümkün görünmektedir. Pandemi döneminde zorunlu uzaktan eğitim süreçleri günümüz uygulamalı birçok dersin uzaktan eğitim yoluyla uygulanmasına imkân sağlamış ve bu derslerin uzaktan eğitim yoluyla uygulanabilirliğine farklı bakış açısı getirerek bir miktar direnci kırdığı ifade edilebilir.

Bu araştırmada, öğrencilerin anketten elde edilen nicel verilerine ilave olarak düşüncelerinin daha derinlemesine incelenebilmesi amacıyla görüş ve önerilerini yazılı olarak iletmeleri istenmiştir. Yapılan içerik analizi ne- 
ticesinde, görüş bildiren öğrencilerin hemen hemen yarısının uzaktan eğitim yoluyla yürütülen fotoğrafçılık dersini verimli bulmadıklarını yazılı olarak beyan etmişlerdir. Bu noktada özellikle uzaktan eğitim sistemi üzerinde nitelikli uygulama gerçekleştirilememiş olmasından kaynakland1ğını belirtmişlerdir. Öğrenciler ayrıca, internet erişimi, cihaz, donanım, bilgisayar gibi uzaktan eğitim sistemine bağlantı gerçekleştirebilecekleri arabirimlerin eksik, az ya da hiç olmaması nedenleriyle ders erişimlerinde zorlandıklarını da belirtmişlerdir.

Öneri sunan öğrencilerin büyük bir kısmı hibrit öğrenme yönteminin uygulanmasını önermişlerdir. Hibrit öğrenme hem yüz yüze öğretim hem de web tabanlı bilgisayar destekli öğretimin beraber uygulandığ 1 harmanlanmış öğrenme yaklaşımlarından biridir (O'Byrne ve Pytash, 2015). Öğrenciler, fotoğrafçıllk dersinin öğrenim sürecinde, kuramsal öğretimleri uzaktan eğitim yöntemiyle, uygulamalı kısımlarını ise yüz yüze gerçekleştirilmesini istemektedirler. Bu araştırma bulgusu itibariyle, Özyürek, Begde, Yavuz ve Özkan (2016) tarafından yapılan araştırma bulgularından olan öğrencilerin uygulamalı dersleri, uzaktan eğitim yerine yüz yüze örgün öğrenim olarak gerçekleştirilmesini istediklerini belirttikleri araştırma sonucuyla benzer paralellik gösterdiği ifade edilebilir.

Pandemi süreçlerinde, bulaş riskini azaltmak amacıyla bireylerin aynı kapalı ortamda, yakın temas içerisinde bulunmaları önerilmemektedir. Ancak, fotoğrafçılık derslerinin uygulamalı bölümleri, açık havada, sosyal mesafenin gözetildiği, seyreltilmiş bir biçimde uygulanma imkânı bulunmaktadır.

Öğrencilerin yazılı görüşlerinin hem anket verileriyle hem de alanyazındaki diğer araştırma bulgularıyla örtüştüğü ifade edilebilir. Ancak bu olumsuz nitelikteki görüşlere rağmen öğrencilerin \%10'luk bir kesimi ise pandemi sürecinde bu şekilde uzaktan eğitim yoluyla uygulamalı dersin yürütülmesinden memnuniyet duyduklarını ifade etmişlerdir. Bu öğrencilerin mesaj içerikleri incelendiğinde sağlık açısından bu şekilde yürütülmesini faydalı buldukları şeklinde yorumlanabilir.

\section{Öneriler}

Fotoğrafçılık dersleri doğası gereği hem kuramsal hem de uygulamalı süreçleri içeren bir derstir. İletişim Fakülteleri haricinde yükseköğretimde 
birçok fakülte ya da meslek yüksekokullarının farklı birimleri altında farklı uygulamalı dersler mevcuttur. Uygulamalı derslerin öğretiminde öncelikli olarak yüz yüze öğretimin tercih edilmesi önerilebilir. Ancak, pandemi, savaş gibi olağanüstü afet olaylarında acil uzaktan eğitim süreçlerinin gerçekleştirilmesi gereken durumlarda, uygulamalı derslerin yürütümünde web tabanlı iletişim teknolojilerinin tercih edilmesi, öğrencilerin yaparak yaşayarak öğrenme süreçlerini gerçekleştirebilmeleri adına çevrimiçi olarak uygulama yapabilmelerine imkân sağlayacak nitelikte ders akışlarının planlanması gerekmektedir. Öğrencilerin kendi kendilerine yaparak yaşayarak öğrenme deneyimlerini kazandırabilmek adına, özellikle mobil cihazları yardımıyla bu deneyimi yaşayabilecekleri kazanım planlamaları yapılabilir. Yılmaz (2020) yükseköğretimde öğrenim görmekte olan öğrencilerinin tamamına yakının mobil akıllı cihaz (cep telefonu) sahip olduğunu belirtmiştir. Bu bağlamda uzaktan eğitim süreçlerinde öğrencilere fotoğraf çekme deneyimlerinin akıllı cep telefonlarının kameraları aracılığıyla yaptırılabilir. Bununla birlikte öğrencilerin fotoğraf makinesinin çalışma prensibini benzeşim (simülasyon) yoluyla gösteren bilgisayar uygulamalarına erişimleri sağlanabilir. Simülasyon uygulamalarının, senkron sanal sınıflarda iş birliği faaliyeti içinde kullanım planlamaları yapılabilir. Uygulamalı derslerin niteliğine göre, çevrimiçi uygulama yapmalarına imkân sağlayacak araçlar tasarlanıp, geliştirilebilir.

$\mathrm{Bu}$ araştırmada veriler anket yoluyla toplanarak öğrencilerin kendi beyanları esas alınarak uzaktan öğrenme deneyimleri ve memnuniyet alg1ları incelenmişti. Farklı değişkenlerle, örneğin başarı değişkeni ile benzer araştırmaların gerçekleştirilmesi önerilebilir.

\section{Etik Kurul Beyanı}

Bu araştırmanın gerçekleştirilmesinde, Uşak Üniversitesi Sosyal ve Beşerî Bilimler Bilimsel Araştırma ve Yayın Etiği Kurulundan 2021-52 sayılı etik kurul onayı alınmıştır. 


\title{
EXTENDED ABSTRACT \\ An Evaluation Regarding the Conducting of Applied Photography Courses via Distance Education

\author{
Erdi Okan Yilmaz \\ Uşak University
}

\begin{abstract}
During the COVID-19 pandemic, many applied courses along with theoretical courses had to be given through distance education. When the literature regarding the teaching of an applied course through distance education is examined, it is seen that the problems are experienced due to the theoretical emphasis of the applied courses through distance education and that it affects student performance negatively. The aim of this study is to examine and evaluate student perceptions about conducting photography lessons in formal education at undergraduate level in the communication faculties through distance education during the pandemic process.
\end{abstract}

Photography course is one of the courses that can be both elective and compulsory with the development of today's digital technologies (Zhou \& Guo, 2018). Basantia (2018) stated that conducting applied courses through distance education is a difficult process, and applied courses include some practical and physical exercises due to their nature. On the other hand, Ağır (2007) emphasized that distance education may cause a decrease in students' motivation and learning performance, especially in lessons that require practice, since there are limitations in socialization. Fojtík (2018) made a comparison about distance education or face-to-face formal taking of courses with practice. He stated that students who take applied courses through distance education are more unsuccessful in terms of academic performance, while they are more successful in face-to-face applied education. Kürtüncü \& Kurt (2020) stated that giving practical courses through distance education is insufficient, lack of face-to-face interaction, limited opportunities and technical problems in the distance education system affect students negatively and increase their anxiety. As a result of the relevant literature review, it was concluded that there may be various difficulties in conducting the applied courses through distance education 
and that it may negatively affect the performance of the students. From this point of view, the necessity of describing the current situation regarding photography courses, which is one of the applied courses that had to be given through distance education during the pandemic process, has emerged from the students' perspectives, that is, with their own perceptions.

Analyzing the quantitative data obtained from the student perceptions questionnaire and the qualitative data obtained from the students' opinions regarding the conduct of a practical course by distance education;

- What are the general satisfaction levels,

- Do satisfaction levels differ according to gender,

- Do their satisfaction levels differ according to their educational background,

- What are the satisfaction levels regarding the theoretical dimension,

- What are the satisfaction levels regarding the applied dimension,

- What are their views on the compulsory distance education process?

- searched for answers to questions.

Mixed explanatory design was used in the study. The photography lesson was taught online for 14 weeks, then a 10-question questionnaire consisting of open and closed-ended questions was developed by the researcher and applied online to the students at the end of the fall semester of the 2020-2021 academic year. The sample of the study consists of 120 undergraduate students studying at the Faculty of Communication of Uşak University. Quantitative and qualitative data obtained from students were analysed and reported. As a result of the research, students were generally not satisfied with the distance education of the applied photography lessons, they thought that it had a negative effect on their learning performance, they thought that the theoretical parts of the courses were efficient, they thought the applied parts of the courses were inefficient, they found the use of materials in online courses useful, and the practical courses were distance education. It has reached the results that they do not want to be carried out through. It is suggested that the theoretical parts of the applied photography courses can be given through distance education, and the applied parts should be done face to face. In terms of this research finding, it can be stated that the students, who are among the research findings of Özyürek, Begde, Yavuz, and Özkan (2016), stated that they 
wanted the applied courses to be carried out as face-to-face formal education instead of distance education. $10 \%$ of the students stated that they were satisfied with the implementation of the applied course through distance education in this way during the pandemic process. When these students' message contents are examined, it can be interpreted that they find it beneficial in terms of health.

It can be suggested that face-to-face teaching should be preferred primarily in the teaching of applied courses. However, in cases where emergency distance education processes need to be carried out in extraordinary disaster events such as pandemics and wars, web-based communication technologies should be preferred in the conduct of applied courses, and course flows should be planned in a way that will allow students to practice online to learn by doing and experiencing. For students to gain experience of learning by doing and living by themselves, acquisition plans can be made, where they can have this experience, especially with the help of their mobile devices. Y1lmaz (2020) stated that almost all his students studying in higher education have a mobile smart device (cell phone). In this context, students can have their photograph-taking experiences made through the cameras of their smart phones during distance education processes. In addition, students can be provided with access to computer applications that show the working principle of the camera through simulation. Simulation applications can be used in collaboration activities in synchronous virtual classrooms. Depending on the nature of the applied courses, tools that will enable them to practice online can be designed and developed.

In this research, the data were collected through a questionnaire and the distance learning experiences and satisfaction perceptions of the students were examined based on the students' self-reports. It may be recommended to carry out similar studies with different variables, for example the success variable.

\section{Kaynakça / References}

Ağır, F. (2007). Özel okullarda ve devlet okullarında çalışan ilköğretim öğretmenlerinin uzaktan eğitime karşı tutumlarının belirlenmesi. Balıkesir: (Yayınlanmamış Yüksek Lisans Tezi). Balıkesir Üniversitesi, Fen Bilimleri 
Enstitüsü, Bilgisayar ve Öğretim Teknolojileri Eğitimi Anabilim Dalı, Balıkesir.

Basantia, T. K. (2018). Implementing practical based courses under open and distance learning system: A study of the perception of learners and counsellors. Turkish Online Journal of Distance Education-TOJDE, 19(2), 201-214.

Bulut, S. and Zor, İ. (2020). Bir kültür üretim aracı olarak fotoğraf ve gündelik yaşamı aktarmada fotoğraf kültürü. İletişim Kuram ve Araştırma Dergisi- Ankara Hacı Bayram Veli Üniversitesi, 50, 74-96.

Büyüköztürk, Ş., Çakmak, E. K., Akgün, Ö. E., Karadeniz, Ş. and Demirel, F. (2013). Bilimsel araştırma yöntemleri (14 b.). Ankara: Pegem Akademi.

Cresswell, J. and Clark, V. (2007). Understanding mixed methods research. Designing and conducting mixed methods research. Los Angeles: Sage Publishing.

Çubukçu, H., Ergeç, N. E. and Gündüz, F. (2017). Fotoğrafçılık uygulamalarının iletişim eğitimi üzerindeki etkisinin incelenmesi. Ç.Ü. Sosyal Bilimler Enstitüsü Dergisi, 26(1), 327-339.

Fojtík, R. (2018). Problems of distance education. ICTE Journal, 7(1), 14-23. doi: https://doi.org/10.2478/ijicte-2018-0002

Gökçe, O. (2006). İçerik analizi (kuramsal ve pratik bilgiler). Ankara: Siyasal Kitapevi, s.63.

Holsti, O. R. (1969). Content Analysis for the social sciences and humanities. USA: Addison-Wesley Publishing Company.

Kahraman, M. E. (2020). Covid-19 salgınının uygulamalı derslere etkisi ve bu derslerin uzaktan eğitimle yürütülmesi: Temel tasarım dersi örneği. IMÜ Sanat Tasarım ve Mimarlı Fakültesi Dergisi, 6(1), 44-56. doi: https://doi.org/10.46641/medeniyetsanat.741737

Korkmaz, A. (2016). Kilis 7 Aralık Üniversitesi uzaktan eğitim sisteminin kullanılabilirlik analizi. International Conference on Quality in Higher Education, (s.486-491). Sakarya.

Krippendorff, K. (2004). Content analysis: An introduction to its methodology. London: Sage Publications.

Kürtüncü, M., ve Kurt, A. (2020). COVID-19 pandemisi döneminde hemşirelik öğrencilerinin uzaktan eğitim konusunda yaşadıkları sorunlar. Avrasya Sosyal ve Ekonomi Araştırmaları Dergisi (ASEAD), 7(5), 66-77. 
Landis, J. R. and Koch, G. G. (1977). The measurement of observer agreement for categorical data. International Biometric Society, 33(1), 159-174. doi: https://doi.org/10.2307/2529310

Langford, M. (2000). Basic photography (7 b.). Oxford: Focal Press.

O'Byrne, W. I. and Pytash, K. E. (2015). Hybrid and blended learning. Journal of Adolescent \& Adult Literacy, 59(2), 137-140. doi: https://doi.org/10.1002/jaal.463

Özyürek, A., Begde, u., Yavuz, N. F. ve Özkan, İ. (2016). Uzaktan eğitim uygulamasının öğrenci bakış açısına göre değerlendirilmesi. Karabük Üniversitesi Sosyal Bilimler Enstitüsü Dergisi, 6(2), 592-605.

Rojprasert, S., Neanchaleay, J., Boonlue, S. and Sinlarat, P. (2020). Designing and implementing constructionist learning in a blended advertising photography course. Int. J. Technology Enhanced Learning, 12(1), 20-37.

Sel, F. (2018). İnönü Üniversitesi uzaktan eğitim öğrencilerinin çevrimiçi öğrenci bağllılk düzeylerinin bazı değişkenler açısından incelenmesi. İnönü Üniversitesi. (Yayımlanmamış Yüksek Lisans Tezi). İnönü Üniversitesi, Eğitim Bilimleri Enstitüsü, Eğitim Programları ve Öğretimi Ana Bilim Dal, Malatya.

Simonson, M. and Schlosser, L. A. (2010). Distance education definition and glossary of terms (3rd edition b.). North Carolina: Information Age Publishing.

Şekerci, Y., Danac1, H. M. and Elinç, Z. K. (2021). Uzaktan eğitimin uygulamalı derslerde sürdürülebilirliği: mimarlık bölümleri örneği. Mehmet Akif Ersoy Üniversitesi Fen Bilimleri Enstitüsü Dergisi, 12(1), 54-68. doi: https://doi.org/10.29048/makufebed.874055

Tekin, H. (1991). Eğitimde ölçme ve değerlendirme. Ankara: Yargı Yayınları.

Torrens University $(2018,10)$. What is 'Practice Based Learning'? (And 3 reasons why it is a great model for educators). Torrens University Australia: https://www.torrens.edu.au/blog/practice-based-learning-foreducators adresinden alınd. Erişim tarihi: Mart 2021.

Yalman, M. (2013). Eğitim fakültesi öğrencilerinin bilgisayar destekli uzaktan eğitim sistemi (Moodle) memnuniyet düzeyleri. Turkish Studies, 8(8), 1395-1406.

Yaman, M. (2009). Perceptions of students on the application of distance education in physical education lessons. Turkish Online Journal of Educational Technology - TOJET, 8(1), 1-10. 
Yılmaz, E. O. (2020). Pandemi sürecinde google classroom uzaktan eğitim sisteminin entegrasyonu ve öğrenci memnuniyet düzeylerinin incelenmesi. Gelecek Vizyonlar Dergisi, 4(3), 42-55. doi: https://doi.org/10.29345/futvis.143

Yılmaz, N. A. (2020). Yükseköğretim kurumlarında covid-19 pandemisi sürecinde uygulanana uzaktan eğitim durumu hakkında öğrencilerin tutumlarının araştırılması: Fizyoterapi ve rehabilitasyon bölümü örneği. Necmettin Erbakan Üniversitesi Sağlık Bilimleri Fakültesi Dergisi, $3(1), 15-20$.

Yolcu, H. H. (2020). Koronavirüs (Covid-19) pandemi sürecinde sınıf öğretmeni adaylarının uzaktan eğitim deneyimleri. Açıköğretim Uygulamaları ve Araştırmaları Dergisi, 6(4), 237-250.

Yükseköğretim Kurulu (2020, Mart). Basın açıklaması. Yükseköğretim Kurulu: https://www.yok.gov.tr/Sayfalar/Haberler/2020/universitelerde-uygulanacak-uzaktan-egitime-iliskin-aciklama.aspx adresinden alındı. Erişim tarihi: Mart 2021.

Yükseköğretim Kurulu (2020, May1s). Yükseköğretim Kurumlarında Uzaktan Öğretime İlişkin Usul ve Esaslar. Ankara. https://www.yok.gov.tr/Documents/Kurumsal/egitim ogretim dairesi/Lzaktan ogretim/yuksekogretim kurumlarinda uzaktan ogretime iliskin usul ve esaslar.pdf adresinden alındı. Erişim tarihi: Mart 2021.

Zhou, S. and Guo, J. (2018). Exploration on the teaching of public art photography course in digital photography age. Advances in Social Science, Education and Humanities Research, 284, 850-852.

\section{Kaynakça Bilgisi / Citation Information}

Yılmaz, E. O. (2021). Uygulamalı fotoğrafçılık derslerinin uzaktan eğitim yoluyla yürütülmesine ilişkin bir değerlendirme. OPUS-Uluslararası Toplum Araştırmaları Dergisi, 18(42), 5673-5698. DOI: 10.26466/opus. 903693. 